\title{
Customers' Expectations and Perceptions of Service Quality of Life Insurance Corporation of India
}

\author{
Effulgence \\ Vol. 16 (Special Issue) \\ January - June, 2018 \\ Rukmini Devi Institute of Advanced Studies \\ E-mail : effulgence@rdias.ac.in, Website :www.rdias.ac.in \\ http://effulgence.rdias.ac.in/user/default.aspx \\ https://dx.doi.org/10.33601/effulgence.rdias/v16/iSpl1/2018/article0.3
}

\section{Mamta Bhushan ${ }^{1}$}

\begin{abstract}
Service Quality is crucial in any business as it helps create the bond between the business and its customers. After the implementation of government policies on globalization and liberalization, the Indian insurance sector has started showing signs of significant change. Life Insurance Sector in India has become highly competitive after opening up of the sector to private insurance companies. In the present era, customers become more critical about the service quality and they are become more aware about the options available in the market related to the services and service providers. Due to increase in customer awareness, customer expectations are rising and the providers should aware about the expectations of the customer and provide prompt, relevant and efficient customer services to survive in the competitive environment. The paper seeks to measure the customers' expectation levels of service quality against their perceptions levels of the service quality in Life Insurance Corporation of India and to determine the gap between customers' expectations and their perceptions of the service quality. The service quality of LIC has been measured on basis of five parameters such as tangibility, reliability, responsiveness, assurance and empathy through SERVQUAL instrument. Data was collected from 120 policyholders of LIC in Delhi and NCR region by using a pre structured questionnaire. Convenience sampling method was used to select the participants. Descriptive statistical analysis, gap mean score and reliability analysis were carrying out. The results suggest that there exist a significant gap in service quality expected and perceived by the customers of LIC which indicate high expectations of policyholders about service quality. So it is recommended that LIC should take corrective measure to improve its customer services on selected dimensions of service quality which help to maintain its status as market leader in the life insurance industry.
\end{abstract}

Keywords: Service Quality, Customers' Expectations, Perception, SERVQUAL.

\section{INTRODUCTION}

L ife insurance is an important and integral part of macro economy and has emerged as most vibrant segment in the financial market in India since liberalization of the market in the year of 2000 .
It plays a very crucial role in promoting saving by selling a wide range of products and also actively contributes in promoting and sustaining the financial market of a nation. Insurance is one of the important needs for every people during their life. In the current life, people always exposed to risk at

\section{Assistant Professor Kamala Nehru College University of Delhi}


anywhere and at any time. Insurance is a one way to reduce it. The primary role of the life insurance sector is to provide protection against personal financial risks. The insurance policy is the contract between the insurer and the insured, which states the risks covered exclusions if any and benefits reimbursed on the happening of the event. Earlier the majority of people do not care about the important of having insurance. But now a days, majority of Indian own at least one insurance policy in order to protect own benefits.

The life insurance industry has experienced immense changes during last two decades due to globalization, new information technology. Liberalization created competitive environment in the country by allowing domestic and foreign private insurance companies in the Indian market. Due to entrance of private insurance companies in Indian life insurance market, customers' expectation and perception of quality of services from the life insurance companies have also changed. In today's competitive business environment, service quality is very important to attract and retain customers. According to Kotler (2000), service delivery is the major driving force to business sustainability. This is due to the fact that customers derive their perceptions of service quality on the levels of satisfaction they experience with a particular business. customers will give an business high marks for its service when it meet or exceed their service desires. Providing a quality service to attract and retain customers has been recognized as a strategic requirement in highly competitive business environments (Parasuraman et al, 1985; Zeithaml etal, 1990. In this era of information, consumers of life insurance have exceptionally high expectations. Due to rising consumer awareness and alternatives available in the competitive market, it is not easy for any player to survive in the market for long-term without fulfilling the expectations of the customers, the life insurance companies have to plan and execute the strategies towards increasing customer satisfaction and loyalty through improved service quality. As insurance is a service industry, the main focus is on the efficient and effective delivery of services to the policyholders. . In the post reform phase, the Life insurance Corporation of India (LIC) is facing challenges from the new competitors entering the market. Therefore, delivering quality service is the only viable The present study has focused on finding customer expectations and perceptions towards service quality as provided by the Life Insurance Corporation of India.

\section{CONCEPTUAL FRAMEWORK}

\section{Life Insurance Corporation of India (LIC)}

There are 24 life insurance companies operating in India, including 23 private and the State owned Life Insurance Corporation of India (LIC). Life Insurance Corporation of India (LIC) has completed its 60 years of its foundation on September 1, 2016. LIC has dedicated the diamond jubilee year to nation. LIC has played a vital role in providing life insurance to common people and in dedicating people's money in public welfare. Started with the initial capital of Rs 5 crore in the year 1956, LIC has now more than Rs 22 lakh crore total assets and life fund of LIC has become worth of Rs 20,57,625.38 crore. Initially LIC was started with 168 offices, now it has 4762 offices, 33161 touch points, 1.14 lakh employees, 10.61 lakh agents and 29 crore current policies. Market stakes of LIC issued in new policies was 76.83 percent and total first yearly premium income was 70.44 percent during the year 2015-16. Once again the LIC's claim settlement ratio was 99.75 percent for maturity claim, which was the best in the insurance industry. LIC has paid total claim amount Rs $85,519.96$ crore to 208.85 lakh claims in the year 2015-16. LIC has always been a leading company to use information technology in order to provide quality service and to improve it. LIC has started the SMS based helpline service, online payment of premium through wallet and SMS alert service on transaction. Costumers could use the E-service for various transactions. All the transactions are completed through NEFT. 


\section{SERVICE QUALITY}

Service quality is a concept that has aroused considerable interest in the literature because of the difficulties in both defining and measuring it (Wisniewski, 2001). There are number of different "definitions" as to what is meant by service quality. There are two types of Service Quality: Technical Quality, which involves what the customer is actually receiving from the service, and Functional Quality, which involves the manner in which the service is delivered (Gronroos 1982). Parsuraman et al. (1985, 1988) positioned and operationalized service quality as a difference between consumer expectations of 'what they want' and their perceptions of 'what they get'. Parasuraman, Zeithaml and Berry (1985) opined that, regardless of the type of service, consumers basically use the same criteria to assess quality. Service quality is nothing but a general customer outlook that the patron perceives regarding its delivery, which is established by a chain of positive or disastrous experiences. Service Quality is the consumers' judgment about an entity's overall excellence or superiority (Zeithmalet al. 1986). It is a form of attitude and results from a comparison of expectations to perceptions of performance received Thus it can be easily inferred that by managing those gaps in service delivery a particular service provider can improve its quality. But no such model was available based on which a customer can give a general feedback on the service they have experienced. With an objective to decipher this problem, Parasuraman, Zeithaml and Berry (1985) developed a methodology commonly known as SERVQUAL where a customer can compare between several orders of expectations and perceptions of service quality regarding the service delivered. This SERVQUAL model pursues to aid managers to comprehend and recognise the sources of problems in quality of service delivered and how to improve those glitches. SERVQUAL is an instrument to measure quality of service perceived by the customer and works with the difference in scores or gaps in the form of a questionnaire. The original SERVQUAL scale uses 22 questions to measure customer's perception of the quality of service delivered based on the five dimensions of service quality: reliability, tangibility, security, empathy and responsibility. These questions are then scored on a Likert scale either from 1 to 7 . The extremes are marked as strongly disagree (1) and strongly agree (7).

\section{Customer expectations and perceptions}

Expectations are the reference point customers have coming into a service experience. Customer expectations from insurance are increasing as they have wider choice of products and services. Customer satisfaction involves understanding customer expectations and meeting them. Customers have different types of expectations about service. A customer's expectation of a particular service is determined by factors such as recommendations, personal needs and past experiences.

Expectations construct at two levels, the first level is desired service, which the level of service the customer hopes to receive, consisting of a blend of what the customer believes can and should be delivered. The second, lower level of expectations is adequate service, which is the level of service the customer will accept. Adequate service is the minimum service a company can provide the still hope to meet customer's basic needs. A zone of tolerance, bounded on the lower end by adequate service and on the upper end bydesired service, captures the range of service within which a company is meeting customer expectations. The level of desired and adequate expectation could vary from customers to customer and potentially from one situation to the next for the same customer Zeithmal (1993).

Customer perception is an important component of our relationship with our customer. They perceive services in terms of the quality of the service and how they are satisfied overall with their experiences. Customer perceptions of the services are influenced by the efficiency of the service provider in delivering 
the service. Customer satisfaction results from the comparison of expectations prior to a purchase with performance perceptions after the purchase. A customer may compare for each dimension of services. Where performance perceptions exceed expectations the customers are delighted to the services.

\section{Dimensions of Servqual Model}

The SERVQUAL model assumes that service quality is multidimensional concept and in turn contributes to the assessment of the service quality in any setting originally ten dimensions of service quality were proposed namely reliability, responsiveness, competences, access, courtesy, communication, credibility, security, understanding the consumer, and tangibles. Later these were reduced to five such as tangibles, responsiveness, assurances and empathy
The expected service and the perceived service sometimes may not be equal, thus leaving a gap. This gap can be filled if the five quality dimensions of SERVQUAL are followed. Five quality dimensions of SERVQUAL as described by Parasuraman, Zeithaml and Berry are:

Tangibles: are the physical evidence of the service. Reliability: is the ability to perform the promised service in a dependable and accurate manner. Assurance: is the customer feeling free from danger, risk or doubts including physical safety, financial security and confidentiality. It involves the factors such as trustworthiness, belief and honesty.

Empathy: means making an effort to understand the customer's individual needs, providing individualized attention, recognizing the customer when they arrive and so on.

Responsiveness: is to the readiness and willingness of employees to help customers in providing prompt timely services.

Table 1 Service Quality Dimensions

\begin{tabular}{|l|l|l|}
\hline Authors & Application Areas & $\begin{array}{l}\text { Service Quality } \\
\text { Dimensions }\end{array}$ \\
\hline $\begin{array}{l}\text { Parasuraman, Zeithaml and } \\
\text { Berry }\end{array}$ & $\begin{array}{l}\text { Telephone,brokerage,banks } \\
\text { and repair } \\
\text { and maintenance }\end{array}$ & $\begin{array}{l}\text { Reliability,Responsiveness, } \\
\text { Assurance,Empathy,Tangi }\end{array}$ \\
\hline Lehtinen & $\begin{array}{l}\text { Restaurants,Hotels,Pubs,Food } \\
\text { Junctions }\end{array}$ & $\begin{array}{l}\text { Corporate Quality, } \\
\text { Physical Quality,Interactive } \\
\text { Process,Output }\end{array}$ \\
\hline Rosen and Karwan & Health care, Teaching & $\begin{array}{l}\text { Reliability,Responsiveness } \\
\text { Assurance,Knowing customers, } \\
\text { Tangibility,Access }\end{array}$ \\
\hline Siu and Cheung & $\begin{array}{l}\text { Retail Stores, Departmental } \\
\text { Stores/Chains }\end{array}$ & $\begin{array}{l}\text { Personal Interaction,Policy } \\
\text { Problem Solving, } \\
\text { Physical Appearance,Promises } \\
\text { Problem Solving,Convenience }\end{array}$ \\
\hline Mehta and Lobo & Life Insurance & $\begin{array}{l}\text { Tangibles,Competence, } \\
\text { Corporate image,Technology } \\
\text { Personalized financial } \\
\text { planning } \\
\text { Assurance }\end{array}$ \\
\hline
\end{tabular}




\section{LITERATURE REVIEW}

In order to find out the gaps in research, the literature already available pertaining to the problem is to be reviewed Review of literature has vital relevance with any research work due to literature review the possibility of repetition of study can be eliminated and another dimension can be selected for the study. The literature review helps researcher to remove limitations of existing work or may assist to extend prevailing study. Several studies have been conducted to analyze the different dimension of service quality of in India and abroad.

Parasuraman et al. (1988), service quality can be defined as an overall judgment similar to attitude towards the service and generally accepted as an antecedent of overall customer satisfaction. Service quality is the ability of the organization to meet or exceed customer expectations. It is the difference between customer expectations of service and perceived service .Perceived service quality results from comparisons by customers of expectations with their perceptions of service delivered by the suppliers. If expectations are greater than performance, then perceived quality is less than satisfactory and hence customer dissatisfaction occurs (Parasuraman et al., 1985; Lewis and Mitchell, 1990).

Berry (1995) suggests that service plays an important role in enhancing value, and can positively influence a firm's success. Understanding and measuring customer expectations and performance are an essential component that can be used to enhance a company's service provision.

Asubonteng et al., ( 1996). Service quality dimensions are likely to be industry specific.

Babakus \& Boller (1992) stated that dimensionality of service quality may depend on the type of service under study

Brady \& Cronin, 2001, State that importance of different dimensions of the service quality depend on the characteristics of the industry

Douglas \& Connor 2003, In spite of the criticality of service quality to businesses, measuring service quality causes difficulties to service providers, as of the unique characteristics of services: intangibility, heterogeneity, inseparability and perish ability

Sachdev and Verma (2004) attempted to explore the relative importance of service quality dimensions in Banking, Insurance, Fast food, and Beauty salon. The study results suggested that in all areas under study, the dimensions; tangibility, reliability, responsiveness, assurance, and empathy are important and there is no significant difference among sectors in the ranking of the dimensions.

Barkur et al.,(2007) identified past experience, personal needs, external communication, word of mouth, and active clients were the key parameters of Service Quality.

Vijaykumar A., (2007) "Globalization of Indian Insurance sector-issues and challenges" found that the need of the nation and its people has finally prevailed and privatization of insurance is now a reality towards further liberalization of the Indian economy. The success of the insurance industry will primarily depend upon meeting the rising expectations of the consumers who will be the king in the liberalized insurance market in future.

Sandhu and Bala (2011) concluded that the three factors namely, proficiency; physical and ethical excellence; and functionality have significant impact on the overall service quality of Life Insurance Corporation of India.

Mittal et al.,(2013) observed that the perceived service quality of Life insurance services is a multidimensional second-order construct consisting of the primary dimensions of service delivery; Sales, Agent Quality, Tangibles and Value of Core Service. 
Pramod Kumara Singhal (2013) studied the service quality in Insurance sector taking private companies of Haryana State.This study was based on the SERVQUAL model covering 500 customers of private insurance companies of 7 districts of Haryana. The study concluded that the people are still carrying a negative impression towards the private insurance companies.

Reza; Pashaie etal., (2013) attempted to evaluate service quality in insurance industry based of customer and personnel view in Kavsar insurance institute, Iran. The study utilized the survey approach. The sample consisted of 319 respondents. The results showed huge gap for reliability, responsiveness and empathy in which reliability showed highest gap between customers" perception and expectation. This research illustrated that reliability emerged as the most critical determinant of SERVQUAL measure of service quality.

Guru Murthy and Chilar Mohamed (2013) studied the level of service quality of Life Insurance Corporation of India with special reference to Chennai District with seven dimensions namely, assurance, personalized financial planning, competence, corporate image, tangibles, technology and ethics.

Rajamani (2013) assessed the Service Quality in Insurance Sector in Virudhunagar district, Tamil Nadu through a SEM approach. The result of the assessment revealed that customers rated reliability" as the most important Dimension.

Prakash and Sugumaran (2014) assessed the perception and expectations of customers in Servqual parameters with reference to Life Insurance Companies in Chennai, India. The sample size of the study was 150 . They have used stratified random sampling technique The factors which are significant are Communications, Competence, Reliability, Security and Courtesy and the expectation levels of these dimensions are significantly higher.
Shamsher Singh et al., (2014) studied the customer perception towards Service Quality of Life Insurance Companies in Delhi NCR Region. The primary data was collected from 139 respondents of Delhi NCR Region. The factor analysis and correlation were used to find the perception of the customers. The study has found that there were four major factors which influence customer perception of service quality namely, responsiveness and assurance, convenience, tangibility and empathy. Only age of respondents have been found to be significantly related with the customer perception and other demographic factors had no significant impact.

Kuldeep Chaudhary et al., (2014) examined the Expected and Perceived Service Quality in Life Insurance Corporation of India. The findings suggested that there exist a significant negative gap in service quality expected and perceived by the customers of the selected company.

Arul and Kannan (2014) conducted a research study to understand the Policyholders" preconception towards Service Quality of Life Insurance Companies in Tamilnadu. The study identified eight service quality factors such as Employee Competence, Credibility, Timeliness and Promptness, Convenience, Accessibility, Communication, Customer Orientation, and Responsiveness. The analyses revealed that the demo graphical variables of the respondents and the eight service quality factors were significantly related.

Urban Sebjan and Polona Tominc (2014) studied the relationships among components of Insurance Companies and Services" Quality through SEM approach. The sample size was 200 Slovenian users of insurance services. The results indicated that higher perceived innovation of insurance company was associated with higher perceived reputation of insurance company.

Heena Kothari (2014) concluded in her study that Service Benefits, Awareness, Risk \& Returns, Tax 
Benefit, Influence in a priority list for buying any life insurance policy and the most influential factor is Service benefits which include prompt services, security and safety and extra added benefits. The study was conducted with the help of Factor Analysis with a sample size of 100 respondents of Indore District.

\section{Research Gap}

During the past two decades, numerous researches have been carried out relating to service quality in different sectors. However, the literature on service quality is not yet rich enough to provide a specific knowledge of the service quality in life insurance companies. The researcher takes this opportunity to partially fill this gap.

\section{OBJECTIVES OF STUDY}

The main objective of the study is to measure and analyze customer's expectation and perception of quality of service provided by Life Insurance Corporation of India.secifically :

1. To measure the significant difference between the expectations and perceptions towards various aspects of service quality in LIC.

2. To determine the of service quality.GAP in LIC

3. To give suggestions to the life insurance sector so that their service quality efforts improve

\section{HYPOTHESES}

H0: There is no significant difference between the expectations and perceptions of customers of LIC

Ha: There is significant difference between the expectations and perceptions of customers of LIC

\section{RESEARCH METHODOLOGY}

Research methodology is the blue print of the study. A good research work requires a clear scientific methodology because only through the application of correct methodology in selection of sampling techniques, appropriate tools of data collection etc; so that well founded conclusion can be drawn on the issues under consideration. The validity of a research depends upon the method of collecting the data and analyzing the same. Descriptive Research design was used for this research based on adoption of survey method. Since the present study constitutes an analytical research, the methodology adopted involves the measurement of service quality using SERVQUAL instrument developed by Parasuraman. The respondents were asked how far they are satisfied with their service provider on a seven-point Likert-type scale including options from strongly dissatisfied to strongly satisfied. The sampling frame for conducting the study comprised with policyholders of LIC residing in Delhi and NCR region. Convenience sampling method was used to select the participants for the reason that it is considered an effortless approach to get respondents to participate in a study of this nature besides; prior related researchers have used the similar method in selecting participants. It is also cost effective as we can choose anyone to be a participant with ease or we can use simple random sampling. The present study is based on primary as well as secondary data. The primary data was collected with the help of a standardized and pre structure questionnaire on expectation and a perception. The 150 questionnaires are distributed, out of which 120 were usable. In total, the response rate was $80 \%$. The secondary data was obtained from books, articles journals, news papers, magazines and other official sources and records. Various websites were also searched to collect the relevant informations. Data collected were analyzed by using various statistical tools. Data were process using SPSS a computerized package available for the data analysis.

\section{DATA ANALYSIS}

Validity Analysis

Content validity: For the present study, the content validity of the instrument was ensured as the service quality dimensions and items were identified from the literature and exploratory investigations, and were thoroughly reviewed by professionals and academicians. 


\section{Reliability Analysis}

A reliability of the instruments was one of the concerns to this study In determining the reliability of the instruments, the Cronbach's Alpha was used to measure reliability of the underlying dimensions i.e. tangible, reliability, responsiveness, assurance and empathy. Cronbach"s alpha is the most widely used measurement tool to measure how well a set of variables or items measure a single, one-dimensional latent construct with a generally agreed lower limit of 0.7. According to Nunnaly 1978, Alpha which is more than 0.7 indicated a high liable.

The following table provides an overview of the reliability scores. As can be seen from this table, all the alpha coefficients were above the required level of 0.7 .

Table 1: Reliability Test for five dimensions

\begin{tabular}{|l|l|l|l|}
\hline Dimensions & $\begin{array}{l}\text { Number } \\
\text { of Items }\end{array}$ & Expectations & Perceptions \\
\hline Tangibility & 4 & .839 & .842 \\
\hline Reliability & 5 & .898 & .895 \\
\hline Responsiveness & 4 & .917 & .893 \\
\hline Assurance & 4 & .904 & .885 \\
\hline Empathy & 5 & .964 & .927 \\
\hline
\end{tabular}

\section{Demographic Profile of the Respondents}

A demographic profile of the respondents consisted of age, gender, marital status, educational qualifications, employment status, and monthly income. The profiles focus on the demographic and economic of respondents.

Table 2: Gender wise distribution of respondents

\begin{tabular}{|l|c|c|}
\hline \multicolumn{1}{|c|}{ Gender } & Frequency & Percent \\
\hline Male & $\mathbf{7 7}$ & $64.17 . \%$ \\
\hline Female & 43 & $35.83 \%$ \\
\hline Total & 120 & 100 \\
\hline
\end{tabular}

Source: Primary data

Above table shows majority of the respondents are male $64.17 . \%$ and $35.83 \%$ of the respondents are female. It is clear that males dominate in purchasing life insurance policies.

Table 3: Marital status wise distribution of respondents

\begin{tabular}{|l|c|c|}
\hline \multicolumn{1}{|c|}{ Marital status } & Frequency & Percent \\
\hline Married & 68 & $56.7 \%$ \\
\hline Unmarried & 52 & $43.3 \%$ \\
\hline Total & 120 & 100 \\
\hline
\end{tabular}

Source: Primary data

Table $356.7 \%$ of the respondents are married and $43.3 \%$ are unmarried. This range shows that married group always feels the importance of insurance policy to complement with their life and families. 
Table 4: Age wise distribution of respondents

\begin{tabular}{|c|c|c|}
\hline Age & Frequency & Percent \\
\hline Upto 25 & 8 & $6.7 \%$ \\
\hline $26-35$ & 19 & $15.8 \%$ \\
\hline $36-45$ & 26 & $21.6 \%$ \\
\hline $46-55$ & 50 & $41.7 \%$ \\
\hline Above 56 & 17 & $14.2 . \%$ \\
\hline Total & 120 & 100 \\
\hline
\end{tabular}

Source: Primary data

It is clear from the above table that on comparing the age group, $41.7 \%$ respondents are in the age group of $46-$ 55 followed by $21.6 \%$ in the age group of $36-45,15.8 \%$ between the age of $26-35,6.7 \%$ below 25 years and. 14.2. \% above 56years.

Table 5: Educational qualification wise distribution of respondents

\begin{tabular}{|l|l|l|}
\hline Educational qualification & Frequency & Percent \\
\hline Below High School & $\mathbf{1 0}$ & $8.3 \%$ \\
\hline High School & $\mathbf{2 2}$ & $18.3 \%$ \\
\hline Undergraduate & $\mathbf{4 8}$ & $40.0 \%$, \\
\hline Post Graduate & $\mathbf{2 7}$ & $22.6 \%$ \\
\hline professional & $\mathbf{1 3}$ & $\mathbf{1 0 . 8 \%}$ \\
\hline Total & 120 & 100 \\
\hline
\end{tabular}

Source: Primary data

Above table shows that most (40.0\%), of the respondents were undergraduate followed by post graduate $22.6 \%$ by high school $18.3 \%$ professional $10.4 \%$ and only $8.3 \%$ respondents are educated below high school It shows that majority of respondents were educated with high qualifications.

Table 6: Occupation wisewise distribution of respondents

\begin{tabular}{|l|l|l|}
\hline Occupation & Frequency & Percent \\
\hline Service & 63 & $52.5 \%$ \\
\hline Business & 21 & $17.5 \%$ \\
\hline professionals & 26 & $21.7 \%$ \\
\hline Others & 10 & $8.3 \%$ \\
\hline Total & 120 & 100 \\
\hline
\end{tabular}

Source: Primary data

Table 6 shows that occupations of respondents were varied. The majority of the respondents were in service group including both private and govt. service. (52.5\%) The majority of people having life insurance are employed. 
Table 7: Monthly income wise distribution of respondents

\begin{tabular}{|l|l|l|}
\hline Monthly income & Frequency & Percent \\
\hline Up to Rs. 20,000 & 23 & $19.2 \%$ \\
\hline Rs.40,001-60,000 & 31 & $25.8 . \%$ \\
\hline Rs.20,001-40,000 & 53 & $44.1 . \%$ \\
\hline Above Rs.60,000 & 13 & $10.8 \%$ \\
\hline Total & 120 & 100 \\
\hline
\end{tabular}

Source: Primary data

In the survey it was also found that the respondents came from different income backgrounds; Family income, majority of the respondents earned monthly income ranges between Rs.20, 000 - Rs.40, 000. .

\section{Hypothesis Testing}

The Gap Analysis is a technique used to identify the Gap - the difference between the level of perception and level of expectation on the various dimensions relating to the services quality, The gap was measured by measuring the difference between perceived service quality and expected service quality for each dimension. The gap for overall service quality score is measured as the difference between average perception score and average expectation score derived from the 22 scale items. The paired't test was employed to test hypothesis.

Table 8: Service Quality Gap

\begin{tabular}{|l|l|l|l|l|}
\hline $\begin{array}{l}\text { Dimensions of } \\
\text { Service Quality }\end{array}$ & $\begin{array}{l}\text { Expectations (E) } \\
\text { Mean score }\end{array}$ & $\begin{array}{l}\text { Perceptions (P) } \\
\text { Mean score }\end{array}$ & Gap (P-E) & $\begin{array}{l}\text { T-value } \\
\text { Significance at } \\
0.05 \text { level }\end{array}$ \\
\hline Tangible & 6.19 & 3.43 & -2.75 & -158.266 \\
\hline Reliability & 5.82 & 4.47 & -1.35 & -181.922 \\
\hline Responsiveness & 5.89 & 3.78 & -2.11 & -216.924 \\
\hline Assurance & 6.16 & 4.48 & -1.68 & -86.758 \\
\hline Empathy & 5.74 & 4.02 & -1.72 & -168.433 \\
\hline $\begin{array}{l}\text { Overall Service } \\
\text { Quality }\end{array}$ & 5.96 & 4.04 & -1.91 & -252.115 \\
\hline
\end{tabular}

The Table 8 furnishes the results of service quality gap analysis (perceptions - expectations) performed in respect of five service quality dimensions. The results indicate that there is a service quality gap in respect of all the service quality dimension under study. Table 7, showed that that actual service was less than expected service in all the dimensions of service quality. the gap mean score shows that tangible (Gap P-E =--2.75);reliability Gap P-E =--1.35, responsiveness( Gap P-E =--2.10); assurance( Gap P$\mathrm{E}=--1.67)$ and empathy (Gap P-E $=--1.70$. ) that means customers expectations is more than actual service perceived .It is quite evident from the results that reliability had the lowest service gap followed by assurance, empathy, responsiveness then tangibles. Also the overall service quality for the Expectation is 5.96 whereas the overall Perception score is 4.04 . This implies that that there is a service quality gap of -1.91 .

The gap for the overall service quality and for all the five dimensions were statistically significant at five 
percent level. So the null hypothesis is rejected there is no significant difference in the mean scores between the level of perception and the level of expectation (GAP) on the various factors in LIC. Higher service quality gaps were found for the dimensions tangibility and responsiveness.

\section{RESULTS AND DISCUSSION}

Data was analyzed by quantifying respondents' responses of their levels of agreement with the statements that were used to evaluate customers' expectations and perceptions of service quality at LIC. The levels of service quality expectations and perceptions were quantified by calculating the average scores on each statement. Scores obtained from calculating the averages for expectations were subtracted from the scores obtained from customers' perceptions on each statement The results revealed that policy holders had higher expectation levels compared to their perceptions of the service quality of LIC on all the service aspects that were used to evaluate the expectations of service quality. Gap 5: Expected Service-Perceived Service was identified .The study shows gap for tangibility, reliability, responsiveness, assurance, and empathy, which tangibility and responsiveness shows highest gap between customers' perception and expectation. LIC need to improve their service attributes that reflected big gaps between customer expectations and their perception levels by focusing more on the tangibles aspect of service quality specifically documentation made, simple and easy, material associated like brochure and pamphlets must clearly specified the terms conditions of policy, employees are neatly appearing and training of employees in order to improve their responsiveness, understanding, assurance and dependability, employees give prompt service within specified time frame.

\section{Recommendations to LIC}

The results of the study have reflected that there are certain dimensions on which customers are little satisfied but certain other dimensions need a lot of improvement to bridge the gap between customer's expectations and perception

1. Keeping the risk adverse nature and customer preference for savings in consideration, focused and localized awareness campaigns and workshops are conducted to further promote benefits of life insurance plans.

2. Documentation should be made easier and faster. i.e. Customer friendly.

3. Brochure and pamphlets must clearly specify the terms conditions of policy.

4. Role of employees and agents in life insurance sector is important to increase the life insurance business as they determine the quality of the service towards a policyholder. Proper training of employees, motivation would help employees to serve the policyholders better.

5. All the hidden charges should clearly be stated in the form and explained by the agent.

6. The company should reduce the initial documentation charges, and agent commission.

7. Claim settlement process should be transparent and fast.

\section{CONCLUSION}

World-wide consumers have become more quality conscious; hence there has been an increased customer demand for higher quality service. Due to globalization and liberalization in service sector, service quality has become an important means of differentiation and way to achieve success in business. In order to compete in intense competitive environment, business firms are creating competitive advantage over their rivals through service quality that will influence customer satisfaction which subsequently leads to customer loyalty. Service quality has been found to be the key strategy of success and survival life insurance sector. This study identified service quality dimensions significant to life insurance sectors. From the research results, this study can conclude that customers' expectations of service quality in Life insurance are higher than their perceptions of service quality at LIC therefore this 
proves that the customer expectation of service quality is not in line with the acceptable levels of service quality in the life insurance sector. Customers have higher service quality expectations that if not met by LIC can result to customer dissatisfaction and losing customers to competitors. But with consistent research in areas like consumer behavior and employee training can fill the gap and satisfy the consumer completely LIC should revise, redesign repackage its service operations and develop strategies that promote reliability to customers, consistency in service delivery. Employees should always be prepared and willing to assist customers which would lead to improve service quality of LIC. We conclude that in today's liberalized environment, insurance companies operate in a market place that is extremely competitive. If LIC focuses on the efficient and effective delivery of services to the policyholders it would enhance its corporate goal of increasing insurance coverage, more profit and increment in market value and share.

\section{Limitations}

Due to shortage of time, only 120 respondent were considered and the study was restricted to Delhi and NCR region. The instrument used in this paper "Servqual" has been criticized by various researchers on a number of grounds.

\section{Further areas for research}

There remains a scope and gap for further research in this domain of knowledge. It can be extended to regional, national level and to other professionally managed organizations. New variables can be developed taking in to account the other aspects of service quality. One can make a comparative study on public and private life insurance sector.

\section{REFERENCES}

\section{A. Books}

1) C.R.Kothari (2005), Research Methodology
Methods and Techniques, New Age International publishers, New Delhi.

B. Journals

1) Asubonteng, P., McCleaty, K. and Swan, J., 1996, "SERVQUAL revisited: a critical review of service quality" Journal of Service Marketing, Vol.10 No. 6, pp. 62-81.

2) Affiaine Ahmad, (2008), "An Assessment on service Quality in Malaysia Insurance Industry", Communications of the IBIMA, Volume 1, pp 1326.

3) Anand Prakash, Sanjay Kumar Jha \& S. P. Kallurkar (2011), "Attitudes of Indians Towards Service Quality for Life Insurance in India", International Journal of Research in Computer Application \& Management, Vol. No. 1, Issue No. 9, pp 57-63.

4) Barkur.G., Varambally,K.V.M., and Rodriques. L.L.R.(2007), “Insurance Sector Dynamics: towards transformation intolearning organization", The Learning Organization, Vol.14, No.6, pp.510-523.

5) Brown. S.W. and Swartz, T. (1989), "A gap analysis of professional service quality", Journal of Marketing, Vol. 53, April, pp. 92-8.

6) Carman, J.M. (1990), "Consumer perceptions of service quality: an assessment of the SERVQUAL dimensions", Journal of Retailing, Vol. 66 No. 1, pp. 33-55.

7) Churchill GA Jr, Surprenant C. An investigation into the determinants of customer satisfaction. Journal of Marketing Research. 1982; 19(11):491-504.

8) Cronin, J. Joseph and Steven A. Taylor (1992), "Measuring Service Quality; reexamination and extension," Journal of Marketing, Vol. 56, pp. 55 -68 .

9) Guru Muthry. R and Chilar Mohamed, P (2013), " A Study of Level of Service Quality of Life Insurance Corporation of India - with Special Reference to Chennai District", GRA-Global Research Analysis, Vol.2, Issue 4, pp.28-33.

10) Kuldeep Chaudhary, Jagdeep Singla and Nisha Chaudhary (2014), “Examining Expected and 
Perceived Service Quality inLife Insurance Corporation of India", International Journal of Application or Innovation in Engineering \&Management, Vol.3, Issue 1, pp.274-282.

11) Lehtinen, J.R. and Lehtinen, O. (1982), "Service Quality : A study of Quality Dimensions", Unpublished Working Paper, Service Management Institute, Helsini.

12) Mittal.S., Gera.R., and Singhvi. S.R (2013), "Developing and Testing a Hierarchical Model of Customer Perceived Service Quality for Life Insurance Services", Asia-Pacific Journal of Management Research and Innovation, Vol.91,pp.63-76.

13) Nunnally, C.J. (1978). Psychometric Theory. McGraw-Hill, New York, NY.

14) Parasuraman, A., Zeithaml, V. and Berry, L. (1985), “A Conceptual Model of Service Quality and its Implications forFuture Research", Journal of Marketing, vol. 49, No.4 pp.41 - 51.

15) Parasuraman, A., Zeithaml, V. and Berry, L. (1988), "SERVQUAL: a multiple item scale for measuring consumer perceptions of service quality", Journal of Retailing, Vol. 64 No. 1, pp. 12-40.

16) Praksh, N and Sugumaran, G (2014), " An Assessment of Perceptions and Expectations of Customer in Servqual Parameters with Reference to Life Insurance Companies in Chennai, India", International Journal of Interdisciplinary and Multidisciplinary Studies (IJIMS), Vol1, No.6, pp.181-184.

17) Pramod Kumar Singhal and Assitha Gupta (2013), “Assessment of Service Quality in Insurance Sector - A Case Study of Private Companies of Haryana State", International Journal of Research in IT \& Management, Vol.3, Issue 1, pp.118-131.

18) Rajamani, M (2013), "Assessment of Service Quality in Insurance Sector - A Sem Approach", Research Journal of Social Science \& Management, Vol.3, No.8. pp.107-11a

19) Sachdev S. B., and Verma, H.V (2004), "Relative Importance of Service Quality Dimensions: A Multi-Sectoral Study,"Journal of Services
Research, Vol.4, No.1, pp.59-82.

20) Sandhu. H.S., and Bala, N (2011), "Customers" Perception towards Service Quality of Life Insurance Corporation of India- A Factor Analytic approach", International Journal of Business and Social Science, Vol.2, No.18, pp.219-231.

21) Shamsher Singh, Naveen J Sirohi and Kumkum Chaudhary (2014), “ A Study of Customer Perception towards Service Quality of Life Insurance Companies in Delhi NCR Region", Global Journal of Management and Business Research: E Marketing, Vol.14, Issue 7, Version 1.0, pp(contains 14 pages)

\section{Websites}

www.irda.gov.in www.licindia.in IRDA Repot 